\title{
EPIDEMIOLOGIC FEATURES OF GUILLAIN-BARRÉ SYNDROME IN SÃO PAULO, BRAZIL
}

\author{
Maria Sheila Guimarães Rocha', Sônia Maria Dozzi Brucki², \\ Alzira Alves de Siqueira Carvalho², Úrsula Waleska Poti Lima ${ }^{3}$
}

\begin{abstract}
Introduction: There are few epidemiologic studies concerning Guillain-Barré syndrome (GBS). Due to difficulties with definition and lack of a standard diagnostic test of reference, GBS is not easy to study epidemiologically. We evaluate some epidemiological features of GBS in a sample of cases treated at a tertiary hospital in São Paulo, Brazil. Method: We retrospectively reviewed all cases of GBS with hospitalization in Santa Marcelina hospital, over the period of January 1995 through December 2002. Results: Ninety-five cases were included in this study. Fifty-five were men and forty women, with a proportion of 1.4 men to 1 woman. The age ranged from 1 to 83 years with a mean age at onset of 34 years. GBS was less frequently observed below 15 years $(18.9 \%)$ and above 60 years $(16.9 \%)$. The highest frequency was observed in patients aged 15 to 60 years old (66.2\%). The annual incidence rate was 0.6 cases/100,000 people. There was a highest frequency of cases during the months of September through March (62.1\%). Conclusion: Our data differs from that of other epidemiological studies in that we did not observe a bimodal distribution in age and found a seasonal pattern in hotter months.
\end{abstract}

KEY WORDS: Guillain Barré syndrome, epidemiology.

\begin{abstract}
Aspectos epidemiológicos da síndrome de Guillain-Barré em São Paulo, Brasil
RESUMO - Introdução: Os estudos epidemiológicos da síndrome de Guillain-Barré são escassos, devido às dificuldades com a definição da doença e à ausência de marcador biológico diagnóstico. Avaliamos aspectos epidemiológicos de uma amostra de pacientes com a SGB internados em hospital terciário da zona leste de São Paulo. Método: Avaliamos retrospectivamente prontuários de internação de todos os pacientes com o diagnóstico de SGB internados no Hospital Santa Marcelina no período de janeiro de 1995 a dezembro de 2002. Resultados e conclusão: A amostra consta de 55 pacientes do gênero masculino e 40 pacientes do feminino, na proporção de 1.4 homens para 1 mulher. A idade variou de 1 a 83 anos (média: 34 anos). Observamos menor incidência da doença em pacientes com idade abaixo de 15 anos $(18,9 \%)$ e acima de 60 anos (16,9\%). A freqüência maior foi observada no subgrupo com idade entre 15 e 60 anos $(66,2 \%)$. A incidência anual foi de 0,6 casos $/ 100,000$ habitantes, sendo $62,1 \%$ dos casos observados nos meses de setembro a março e 37,9\% nos meses de abril a agosto. A mortalidade observada foi de 3,1\%. Conclusão: Nossos resultados diferem daqueles publicados na literatura médica pela ausência de distribuição bimodal na idade e pelo caráter sazonal apresentado.
\end{abstract}

PALAVRAS-CHAVE: síndrome de Guillain-Barré, epidemiologia.

Guillain-Barré syndrome (GBS) covers a set of clinical syndromes in which idiopathic peripheral neuropathy affecting motor, sensitive and autonomic nerves and spinal roots causes acute, or subacute, progressive motor weakness in more than one limb ${ }^{1,2}$. The degree ranges from minimal weakness in the legs to total paralysis of the muscles of all four extremities and of the trunk. External ophthalmoplegia, bulbar and facial paralysis may occur with varied frequency. GBS has near complete, or complete, clinical recovery in most cases ${ }^{3}$. It is mediated by humoral and cellular immune responses that result in the direct destruction of either the myelin sheath surrounding the peripheral nerves or the axon itself ${ }^{4}$. Immune reactions against target epitopes contained in Schwann cell surface membrane or myelin result in acute inflammatory demyelinating neuropathy, and reactions against epitopes in the axonal membrane cause the acute axonal form of the syndro$\mathrm{me}^{5}$. It may follow triggering events, most frequently nonspecific or "flu-like" upper respiratory

Serviço de Neurologia Clínica do Hospital Santa Marcelina (HSM), São Paulo SP, Brasil; ${ }^{1}$ Doutora em Medicina, Chefe do Serviço de Neurologia Clínica HSM; ${ }^{2}$ Doutora em Medicina, Assistente do Serviço de Neurologia Clínica HSM; ${ }^{3}$ Residente de Neurologia do HSM.

Received 27 May 2003, received in final form 15 August 2003. Accepted 13 September 2003.

Dra. Maria Sheila Guimarães Rocha - Rua Gandavo 100/111 - 04023-000 São Paulo SP - Brasil. E-mail: msrocha@uol.com.br 
infections, gastrointestinal illnesses and vaccinations ${ }^{6,7}$. Nowadays Guillain-Barré syndrome has become the principal cause of acute flaccid paralysis in Western countries, after the control of poliomyelitis ${ }^{8,9}$.

Epidemiological studies can provide a more complete picture of the natural history and clinical spectrum of a disease, mainly when the studies are based on all cases of the disease in a well defined population. Peripheral neuropathies are definitively not easy to study epidemiologically, due to the heterogeneity of the disorder and because many different clinical disorders have neuropathy as a component. Guillain-Barré syndrome is a subgroup of neuropathy and its diagnosis remains descriptive. We still have difficulties with its definition and there is not a standard diagnostic test of reference. Epidemiological studies of GBS are rare, with only ten series that include more than one hundred patients to date ${ }^{10-16}$. This occurs partially because the clinical, laboratory and electrodiagnostic criteria, although well defined, are difficult to apply retrospectively. Despite these caveats, GBS has been the subject of many epidemiological studies given that it is a striking neurologic condition and usually serious enough to require medical attention at a very early stage.

To our knowledge, there have been just a few epidemiological studies of this syndrome in Latin American $8,9,17,18$. The aim of this study is to demonstrate clinical and epidemiological aspects of GBS in a series of ninety-five Brazilian patients whose illness occurred over the years from 1995 to 2002.

\section{METHOD}

We included all patients with clinical diagnosis of GBS who had been hospitalized in Santa Marcelina Hospital, São Paulo, Brazil, from January 1995 to December 2002. Clinical data was collected from medical records of the patients whose hospitalization occurred during the period of 1995 to 1999, and from clinical registrations for cases occurring during the years of 2000 to 2002. We used a standard protocol that included demographic data and a questionnaire in order to disclose possible risk factors for GBS. We also applied clinical, electrophysiological and cerebrospinal fluid (CSF) criteria for GBS defined by Asbury and Cornblath ${ }^{3}$. Patients were included only if they fulfilled all criteria defined by Asbury and Cornblath: presence of roughly symmetrical motor weakness over a period ranging from days to four weeks and decrease or disappearance of deep tendon reflexes. All the patients were examined by the same neurological staff during all these years. They all underwent CSF biochemical analysis and electrodiagnostic studies. Patients were excluded if they had Diabetes mellitus or acquired immunodeficiency syndrome, since these illnesses are related to acute inflammatory demyelinating polyneuropathy, and thereafter present a high possibility of bias in an epidemiological study.

\section{RESULTS}

Ninety-five patients met diagnostic criteria of Asbury and Cornblath for GBS and were included in statistical analysis. (Figs 1 and 2) Fifty-seven percent of the patients were male and $43 \%$ were female, with a male/female ratio of $1.4 / 1.0$. The mean age of the 95 patients at admission was 35 years (range 1 to 83). The female group was significantly younger than the male group. The female group had a mean age of 30 years (range 1 to 79) and the male group had a mean age of 39 years $(p<0.05)$. The analysis of subgroups of ages showed a higher proportion of patients aged 15 to 60 years ( $66.2 \%$ of all cases), and a small proportion of patients with age below fifteen $(18.9 \%)$ and above sixty (16.9\%). The analysis of the children subgroup showed an increased frequency among children aging 0-4 years (55.5\%).

The annual mean coefficient of incidence of GBS was 0.4 per 100.000 persons considering both sexes and all ages of the population located at Santa Marcelina Hospital area (three million people). The mean annual frequency was 11.9 cases. Considering seasonal fluctuations, the highest incidence was observed from September to March with $62.1 \%$ of cases and $37.9 \%$ during the months of April to August $(p<0.05)$. Table 1 shows a higher incidence of GBS during the months of Spring and Summer in six out of eight years. Antecedent infections within one month before the onset of neurological symptoms were found in fifty-eight percent of the cases. Among them, respiratory infections were related in $\mathbf{4 6}$ percent of cases, and gastrointestinal infections in $12 \%$ of cases.

The initial symptoms were ascending in $86 \%$ of the cases. Respiratory failure with mechanical ventilatory support was observed in $19 \%$ of cases. Facial paralysis occurred in $40 \%$ of the patients and was bilateral in $70 \%$ of these cases. Oculomotor disturbance occurred in $35 \%$ of patients while urinary dysfunction was observed in only three patients. Sensory disturbances, including pain, were observed in $10 \%$ of all cases. Three patients died from respiratory failure and pneumonia or sepsis, with a mortality ratio of $3.1 \%$. 


\section{DISCUSSION}

Incidence - Forty large series of GBS patients from well-defined geographic areas were identified over the last 45 years ${ }^{19}$. Annual incidence has varied widely, from 0.4 to 4 cases $/ 100,000$ population with a median of 1.3 cases $/ 100,000$. Our series of GBS patients disclosed a mean annual incidence of 0.4 case $/ 100.000$. Although definitely not representative of the Brazilian population, as this was a hospital-based study, it showed an annual incidence similar to a recently published study, which analyzed the GBS in the whole Brazilian population under 15 years of age ${ }^{9}$. They found a mean coefficient of incidence of 0.46 for the whole country and 0.40 for the southeast region, where lies the city of São Paulo. These data, however, cannot be compared with that from the present study, since our survey included all age subgroups. In spite of that, our data showed an annual incidence that is not different from the overall incidence rates recorded in many other studies, ranging from 0.2 to 0.9 case $/ 100.000^{10,19-22}$. We did not consider the population of São Paulo's metropolitan area because all the patients in this series lived in the hospital referred area. The annual incidence of the cases (given in Table 1) showed no increasing incidence during these eight years, although we have observed a peak incidence in 1996 (Fig 1).

Sex distribution - In almost all series studies, males are more commonly affected by GuillainBarré syndrome than are females, with a median rate of 1.25 men to one woman ${ }^{22}$. Considering the supposed autoimmune etiology of GBS, the male preponderance is somewhat unexplained. We also observed the same preponderance in our study with a male/female ratio of 1.4/1.0. DiasTosta and Huckelhaus found a slight preponderance of boys throughout the years of their study in the Brazilian population below fifteen ${ }^{9}$. Our study also showed that men were older than women at the onset of the disease. We do not have a reasonable explanation for that. Perhaps this represented only a statistical bias in consequence of the difference between the numbers of cases in both sexes.

Age distribution - The age distribution of GBS is usually bimodal, with peaks both in the young and the elderly ${ }^{22}$. The incidence is lower in children under fifteen, whereas the highest incidence is observed in the elderly. This increased incidence in the elderly is commonly attributed to an abnormal immune suppressor mechanism, leading to higher susceptibility to autoimmune disorders. Our study failed to demonstrate this bimodal age distribution. We saw an isolated peak in young adult, mainly in those between 15 to 40 years old, and lower incidences in children and in patients above 60 years old (Fig 2). Among children the greater prevalence was observed in tho-

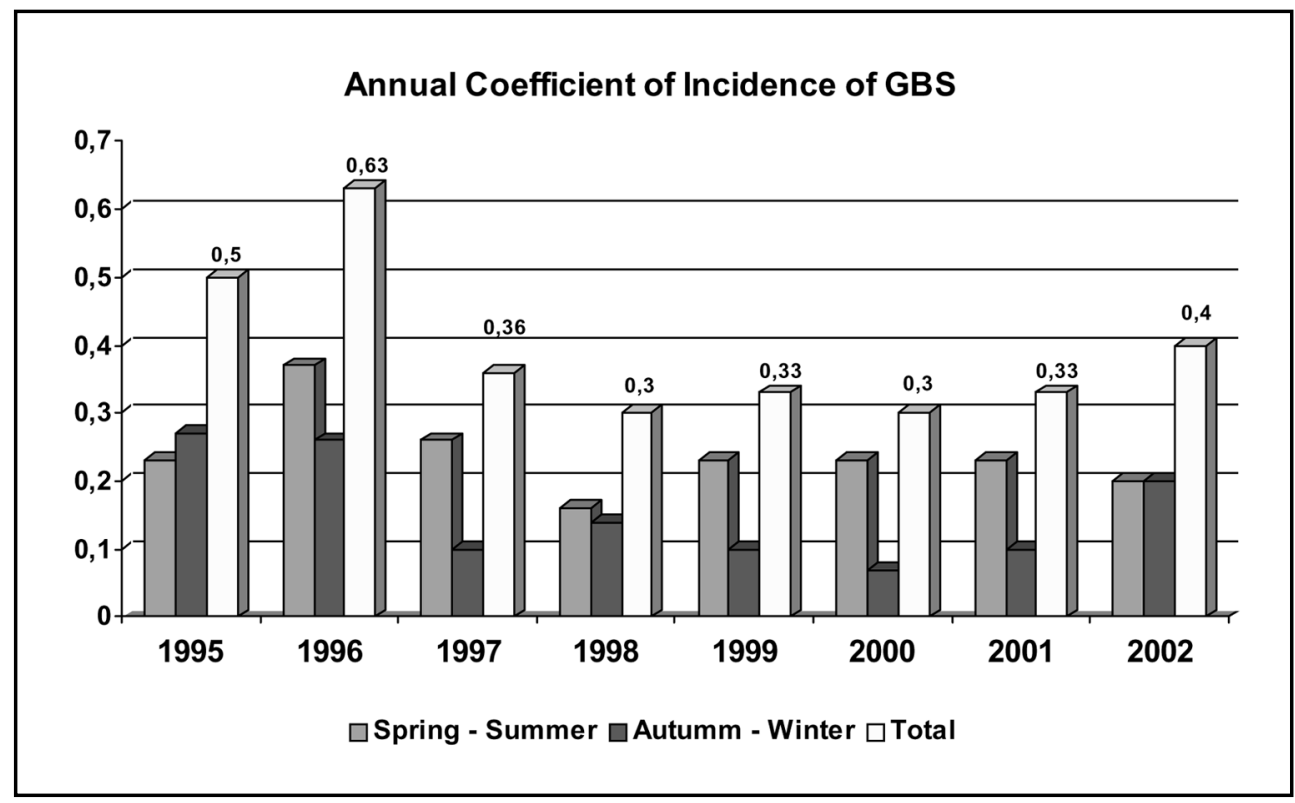

Fig 1. Annual coefficient of incidence of GBS and incidence in the Spring-Summer and AutumnWinter months over the years 1995 to 2002. 


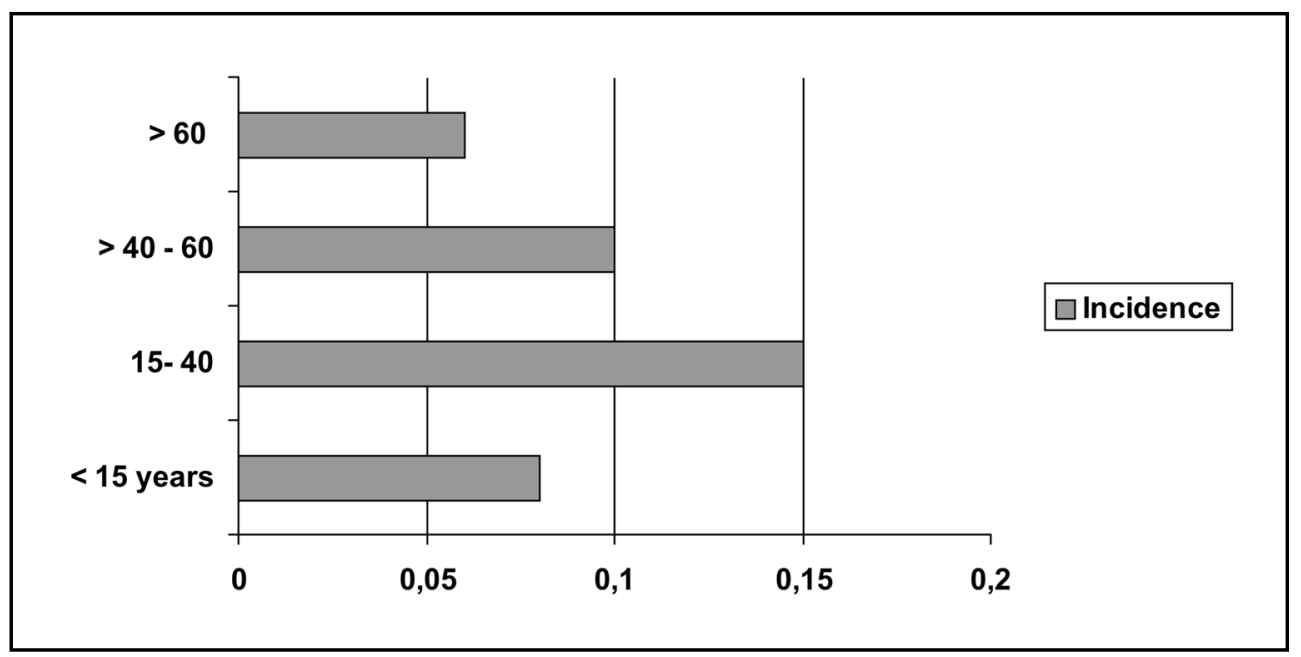

Fig 2. Age distribution of patients with GBS and their respective mean annual coefficients of incidence.

se under four years old. We had a lower incidence in the age subgroup below fifteen than that found in Dias-Tosta and Huckelhaus series of patients ${ }^{9}$, although we had observed the same high prevalence in children below four as they had. Probably this reflected the influence of the lack of pediatric emergency reference to our hospital, known as a general one.

Seasonal distribution - Most studies have not identified a relationship between the incidence of GBS and season preponderance, despite the clear association with preceding upper respiratory infections, which are more frequent in the colder months of winter. Some epidemiological studies show a seasonality pattern, such as those studies that identify a higher frequency of the disease in autumn ${ }^{23}$, or in the summer and autumn ${ }^{13,24}$ along with the study in Sardinia, Italy, which reported the most critical seasons to be Winter and Spring ${ }^{10}$. A study in northern China has found a markedly increased incidence of the acute motor axonal form of GBS in the Summer months. This form of the disease is clearly associated with enteric infections and Campilobacter jejuni, with higher incidence in hotter months ${ }^{25}$. The lack of seasonal association observed in most studies may be due to the fact that the respiratory and enteric infections have opposite seasonality. We found a higher incidence of the illness in the months during Spring and Summer in Brazil, when sixty-two percent of the cases occurred (Table 1). This cannot be attributed to enteric infections like in China, since the most frequent trigger event in our series was respiratory tract infections. DiasTosta and Kuckelhaus' study, also in Brazil, shows no clear peak distribution against months, although they had found a slight variation in January and May, which was not significant ${ }^{9}$.

Trigger events - GBS is the prototypic "postinfectious" disease, with about two-thirds of patients with an antecedent infection, but in many instances, the pathogen that caused the prodromal illness remains unidentified. Respiratory infections are the most frequently reported, followed by gastrointestinal infection, of which Campilobacter jejuni is the main identified agent ${ }^{26}$. Many other identified pathogens have been reported, including human immunodeficiency virus, as being triggers for GBS, but these have been reported in small series and anecdotal reports, for which there is a lack of statistically valid eviden$\mathrm{ce}^{27}$. The association with vaccinations has been reported in many studies as antecedent events ${ }^{14}$, but the only case with a satisfactorily explained mechanism is that of the rabies vaccines. Two separated case control studies failed to show a significant association between the occurrence of GBS and immunization, although they have found an increased risk likely to be four to five-fold ${ }^{28}$. Other possible life event associations, such as pregnancy, surgery and trauma, have been reported as remote etiologic possibilities ${ }^{22}$. We found the respiratory infection to be the most frequently antecedent trigger event, being reported by $46 \%$ percent of our patients, followed by gastrointestinal infection, reported by $12 \%$ of patients. None of our ninety-five patients reported previous vaccination, trauma, surgery or pregnancy.

Mortality - The death rate of GBS ranges from 5 to $10 \%$ even in regions of high standard medi- 
cal care quality and remains a significant cause of mortality and morbidity among persons aged over 40 years. Mortality rate increases among older age groups. The overall case-fatality ratio is about $4.4 \%$ in the United States, ranging from $0.7 \%$ among persons younger than fifteen years old to as high as $8.6 \%$ among persons older than 65 years old $^{29}$. In southeast England the mortality ratio was also about $8 \%$, as it was demonstrated in a recent survey by Rees et al. ${ }^{30}$. Dias-Tosta \& Kuckelhaus found a death rate of $5.4 \%$ in a Brazilian series of pediatric GBS, with a regional variation from $2.7 \%$ in the southeastern part of Brazil to $7.6 \%$ in the northeast region 9 . We found a mortality ratio of $3.1 \%$. The three patients who died were over 60 . The mortality rate observed in our study was slightly lower than those discussed above, probably reflecting a constant concern over early critical care measures, and early use of plasmapheresis or high dose intravenous immunoglobulin, the standard treatment defined for all patients with certain diagnosis of GBS in our centre since 1995.

In conclusion, our study demonstrated incidence, sex distribution and trigger events of GuiIlain-Barré Syndrome similar to many other previous studies. However, our data differs from that of other epidemiological studies in that we did not observe the typical bimodal distribution in age, there was a slightly lower mortality than worldwide described and we have found a seasonal preponderance in hotter months.

\section{REFERENCES}

1. Griffin JW, Li CY, Ho TW, et al. Guillain-Barré syndrome in northern China. The spectrum of neuropathological changes in clinically defined cases. Brain 1995;118:577-595.

2. Hartung HP, Pollard JD, Harvey GK, Toyka KV. Immunopathogenesis and treatment of the Guillain-Barré syndrome. I. Muscle Nerve 1995;18:137-153

3. Asbury AK, Cornblath DR. Assessment of current diagnostic criteria for Guillain-Barré syndrome. Ann Neurol 1990;27(Suppl):S21-S24.

4. Koski CL. Humoral mechanisms in immune neuropathies. Neurol Clin 1992;10:629-649.

5. Hafer-Macko CE, Sheikh KA, Li CY, et al. Immune attack on the Schwann cell surface in acute inflammatory demyelinating polyneuropathy. Ann Neurol 1996;39:625-635.

6. Alter M. The epidemiology of Guillain-Barré syndrome. Ann Neurol 1990;27(Suppl):S7-S12.
7. Lasky T, Terracciano GJ, Magder L, et al. The Guillain-Barré syndrome and the 1992-1993 and 1993-1994 influenza vaccines. N Engl J Med 1998;339:1797-1802.

8. Olive JM, Castillo C, Garcia CR, Quadros CA. Epidemiologic study of Guillain-Barré syndrome in children $<15$ years of age in Latin America. J Infect Dis 1997;175(Suppl 1):S160-S164.

9. Dias-Tosta E, Kuckelhaus CS. Guillain Barré syndrome in a population less than 15 years old in Brazil. Arq Neuropsiquiatr 2002;60:367-373.

10. Congia S, Melis M, Carboni MA. Epidemiological and clinical features of Guillain-Barré syndrome in Sardinia in the 1961-1980 period. Acta Neurol 1989;11:15-20.

11. Jiang GX, Cheng Q, Link H, Pedro-Cuesta J. Epidemiological features of Guillain-Barré syndrome in Sweden, 1978-1993. J Neurol Neurosurg Psychiatry 1997;62:447-453.

12. Hankey GJ. Guillain-Barré syndrome in Western Australia, 1980-1985. Med J Aust 1987;146:130-133.

13. Larsen JP, Kvale G, Nyland H. Epidemiology of the Guillain-Barré syndrome in the county of Hordaland, Western Norway. Acta Neurol Scand 1985;71:43-47.

14. Langmuir AD, Bergman DJ, Kurland LT, Nathanson N, Victor M. An epidemiological and clinical evaluation of Guillain-Barré syndrome reported in association with the administration of swine influenza vaccines. Am J Epidemiol 1984;119:841-879.

15. McLean M, Duclos P, Jacob P, Humphreys P. Incidence of GuillainBarré syndrome in Ontario and Quebec, 1983-1989, using hospital service databases. Epidemiology 1994;5:443-448.

16. Nyland H. Epidemiology of Guillain-Barré syndrome in mid-western Norway. Acta Neurol Scand 1978;57:223-231.

17. Hart DE, Rojas LA, Rosario JA, Recalde H, Roman GC. Childhood Guillain-Barré syndrome in Paraguay, 1990 to 1991. Ann Neurol 1994; 36:859-863.

18. Lamenha JA, Lyro AS. Acute multiradiculopathy: report of 56 cases Arq Neuropsiquiatr 1993;51:112-117.

19. Cheng $Q$, Wang $D$, Jiang $G$, et al. Distinct pattern of age-specific incidence of Guillain-Barré syndrome in Harbin, China. J Neurol 2002, 249:25-32.

20. Brewis M, Poskanzer DC, Rolland C, Miller H. Neurological disease in an English city. Acta Neurol Scand 1966;42(suppl 24):1-89.

21. D'Ambrosio G, De Angelis G, Vizioli R. Epidemiology of GuillainBarré syndrome in Campania (South Italy): preliminary results. Acta Neurol 1983;23:245-252.

22. Hughes RAC, Rees JH. Clinical and epidemiological features of Guillain-Barré syndrome. J Inf Dis 1997;176(Suppl 2):S92-S98.

23. Ravn H. The Landry-Guillain-Barré syndrome. Acta Neurol Scand 1967;43(Suppl 30):1-18.

24. Lesser RP, Hauser WA, Kurland LT, Mulder WM. Epidemiologic features of the Guillain-Barré syndrome. Neurology 1973;23:1269-1275.

25. McKhann GM, Cornblath DR, Griffin JW, et al. Acute motor axonal neuropathy: a frequent cause of acute flaccid paralysis in China. Ann Neurol 1993;33:333-342

26. Winer JB, Hughes RAC, Anderson MJ, Jones DM, Kangro H, Watkins RFP. A prospective study of acute idiopathic neuropathy: antecedent events. J Neurol Neurosurg Psychiatry 1988;51:613-618.

27. Arnason B, Soliven B. Acute inflammatory demyelinating polyradiculoneuropathy. In Dyck PJ, Thomas PK, Griffin JW, Low PA, Poduslo JF (eds). Peripheral neuropathy, $3^{\text {rd }}$ Ed. Philadelphia: Saunders, 1993 : 1437-1497.

28. Hughes RAC, Rees J, Smeeton N, Winer J. Vaccines and GuillainBarré syndrome. Br Med J 1996;312:1475-1476.

29. Prevots DR, Sutter RW. Assessment of Guillain-Barré syndrome mortality and morbidity in the United States: implications for acute flaccid paralysis surveillance. J Inf Dis 1997;175(Suppl1):S151-155.

30. Rees JH, Thompson RD, Smeeton NC, Hughes RAC. Epidemiologica study of Guillain-Barré syndrome in southeast England. J Neurol Neurosurg Psychiatry 1998; 64:74-77. 